An exploratory study of international opportunity identification among family firms

Dr. Reza Zaefarian, Faculty of Entrepreneurship, University of Tehran, 16th Street, North Karegar Avenue, Tehran, Iran

Email: rzaefarian@ut.ac.ir

Corresponding Author: Prof. Teck-Yong Eng, TO BE COMPLETED

Dr. Misagh Tasavori, Essex Business School, University of Essex,

Elmer Approach, Southend on Sea, Essex, SS1 1LW, United Kingdom

Email: tasavori@essex.ac.uk 


\title{
An exploratory study of international opportunity identification among family firms
}

\begin{abstract}
This research examines how family firms identify international opportunities. Family firms are characterised by long-term orientation, being risk averse, and benefiting from familiness capital, resources and capabilities related to family involvement and interactions. Built upon opportunity identification theory and in two perspectives of accidental discovery and purposeful search, we explore the role of social and business networks, and prior knowledge in a first and subsequent international opportunity identification by family firms. In addition, we attempt to understand the role of family characteristics in the process of opportunity identification. Multiple case studies were carried out with seven family businesses from emerging economies, namely, India, Turkey and Taiwan. The findings of this research illustrate that because of being risk averse and long-term oriented, family firms are more likely to identify the first international opportunity through accidental discovery and subsequent international opportunities through purposeful search. The findings of this research show that, as risk-averse firms, family firms are not proactive in initiating international opportunity identification but rather learn about opportunities through accidental discovery. After the first experience of internationalisation, family firms engage in a more purposeful search to identify avenues that will aid their longevity through internationalisation. In the identification of firms' first international opportunities, it is mainly social networks that play a crucial role, especially those that contain international industry and market-specific knowledge. There is also a positive relationship between a family entrepreneur's prior knowledge and international opportunity identification and this relationship is moderated by the prior knowledge of their network. Familiness capital of these organisations can also play a role in long-term international opportunity identification.
\end{abstract}

Key words: International opportunity identification, family business, emerging markets, social networks, business networks, familiness, case study 


\section{Introduction}

The primacy of opportunity identification in international markets is well established (Eckhardt \& Shane, 2003; Ozgen \& Baron, 2007; Zahra, Korri, \& JiFeng, 2005) in the field of international entrepreneurship. Opportunity can be defined as the possibility of introducing a new product to the market with the potential for financial gain (Lee \& Venkataraman, 2006). Opportunity identification is a critical part of the internationalisation process as it guides firms as to where to start and how to direct their internationalisation efforts (Chandra, Styles, \& Wilkinson, 2009). This study explores international opportunity identification in the context of family firms as there is limited empirical research that has documented the practice in this context (Kontinen \& Ojala, 2010). Family firms may demonstrate different behaviour in the identification of opportunities (Kontinen \& Ojala, 2010, 2011a), though prior studies have mainly focused on the process of international opportunity exploitation (Styles \& Gray, 2006).

Drawing upon opportunity identification theory (Ardichvili, Cardozo, \& Ray, 2003), this study aims to examine how family firms identify international opportunities. Specifically, the objectives of this study are to: (a) examine whether family businesses identify international opportunities through accidental discovery or purposeful search; (b) the extent to which social and business networks are employed in the identification of international opportunities; (c) explore the nature of prior knowledge employed by those firms in recognising international opportunities; and (d) examine how family firms' characteristics influence the identification of international opportunities. To achieve these objectives, multiple case studies were conducted with seven small and medium-sized family enterprises (i.e. family SMEs) from three emerging economies, namely, Taiwan, Turkey and India.

This research offers several contributions. First, it adds to the international business literature and internationalisation theories by highlighting the factors that influence international opportunity identification in family firms. This adds to the existing knowledge about the development of international business in family firms (Kontinen \& Ojala, 2010). Second, this research offers better understanding of Ardichvili et al.'s (2003) theory of opportunity identification in the context of international activities of family firms. The present study also provides insights into the behaviour of family manufacturing firms from emerging economies. 
This article is organised as follows. First, the characteristics of family firms and prior research on international opportunity identification are reviewed. Then, the research method, the empirical analysis and the discussion of the findings are presented. This is followed by an explanation of the conclusions and contributions of the research.

\section{The context of family firms and international opportunity identification}

There are various understandings of what is meant by family firms (Kontinen \& Ojala, 2010). In this research, we adopt the comprehensive definition suggested by Abdellatif, Amann, and Jaussaud (2010). According to them, family firms should meet three conditions: (1) one or several family members hold a significant part of the company's capital, (2) family members retain significant control over the business, and (3) family members hold top management positions. Studies show that family firms are characterised by several distinctive factors, including familiness capital, long-term orientation, and risk averseness (Chrisman, Chua, \& Steier, 2005; Patel \& Fiet, 2011), which are explained below.

Familiness capital - Familiness can be defined as "resources and capabilities related to family involvement and interactions" (Chrisman, Chua, \& Litz, 2003, p.468). Family firms provide a unique context in which family members, the family, and the business interact with each other (Chrisman, et al., 2005). Greater interdependence and more interaction among the family create a greater level of trust, and higher degree of reciprocity and exchange among the family members. For example, parents support their children without the use of specific repayment plans but under the implicit promise that the children will eventually care for the family and the family business (Bubolz, 2001). In addition, being raised by the family, the children have a better understanding of the family values and accepted behaviour, which can contribute to the integration, cohesion, and survival of the family unit (Bourdieu, 1994, p.139). The uniquely strong ties offered by kinship are viewed as an important resource required for opportunity identification (Hayton, Chandler, \& DeTienne, 2011). Sardeshmukh and Corbett (2011) point out that, as a result of being trained by the family, and because of the experience of working within the family firm, the successors of family firms are confident in their ability to recognise the right opportunities.

Long-term orientation is defined as "the tendency to prioritize the long-range implications and impact of decisions and actions that come to fruition after an extended time 
period" (Lumpkin, Brigham, \& Moss, 2010, p.241). In comparison with non-family firms, family firms have a greater interest in their long-term performance (Walsh \& Seward, 1990; Zellweger, 2007). Most family firms attempt to make their decisions in such a way as to ensure that the business can be passed on to the succeeding generation (Poza, 2007; Ward, 2004). This long-term orientation of family firms may enable them to engage in longer-term international opportunity identification practices and build internal knowledge structures that can contribute to the finding of international opportunities (Carney, 2005; Patel \& Fiet, 2011).

Risk averseness - Risk taking is related to the willingness of the firm to venture into the unknown without certain knowledge of the possible outcomes (Covin \& Slevin, 1991). Compared to non-family firms, family firms are usually characterised as being more risk averse. In a study of 696 Swedish SMEs (265 family and 431 non-family), Naldi, Nordqvist, Sjöberg, and Wiklund (2007) found that family firms take fewer risks than non-family firms. As family firms usually rely on their own assets, they pursue strategies that reduce the risk of financial failure. On the one hand, internationalisation and international opportunity recognition are usually postponed because of concerns regarding the family's wealth (Schulze, Lubatkin, \& Dino, 2002). On the other hand, family firms' risk averseness may influence the process by which they seek international business opportunities.

\section{Background theory}

There are two competing perspectives of opportunity identification, accidental discovery and purposeful search, which are explained in section 3.1. Ardichvili, et al. (2003) highlight several factors that can contribute to opportunity recognition within each of these perspectives. These factors include network ties and prior knowledge, which are explained in sections 3.2 and 3.3 respectively.

\subsection{Opportunity identification perspectives: Accidental discovery versus purposeful search}

There are two perspectives in terms of the way opportunities are identified: accidental (serendipity) discovery and purposeful search (deliberation) (Ardichvili, et al., 2003; Chandra, et al., 2009). The former argues that the recognition of an opportunity occurs in a 
moment of insight and is the result of an accidental discovery (Gaglio \& Katz, 2001). Family entrepreneurs do not search for opportunities but recognise the value of information that they happen to receive (Ardichvili, et al., 2003; Koller, 1988). Kirzner (1979, p.56) defines alertness as "notice[ing] without search[ing]". According to the advocates of this perspective, although family entrepreneurs may be engaged in other activities, implying that a systematic search would be impossible for them (Fiet, 2007), they are able to discover opportunities because of being alert (Ardichvili, et al., 2003; Shane \& Venkataraman, 2000). In this perspective, family entrepreneurs have an extraordinary ability to "smell" opportunities, allowing them to pick up on overlooked opportunities (Kirzner, 1979; Tang \& Khan, 2007).

In contrast, the process of opportunity identification is the result of a purposeful, rational, and systematic search which takes place over time (Bhave, 1994; Fiet, Piskounov, \& Patel, 2005). Searching refers to family entrepreneurs' attempts to "find signals related to a specific set of criteria where a signal is new information that changes understanding about the future" (Fiet, 2007, p. 593). Kirzner (1997) explains that entrepreneurs search for pieces of missing information which they are aware are missing. The family entrepreneur knows what he/she does not know and as a result knows what he/she is searching for.

In the context of family firms, Hayton, et al. (2011), for example, argue that family firms are less likely to enter international markets proactively when they do not know much about them. Graves and Thomas (2008) highlight that family businesses are reactive in recognition of their first international opportunities and proactive in recognition of subsequent international opportunities. In contrast to this, Kontinen and Ojala (2011a) show that even in the identification of subsequent opportunities, family firms are reactive rather than proactive. Thus, an understanding of family firm characteristics may help family businesses to identify international business opportunities.

\subsection{Network ties}

Social networks. Social networks comprise the relationships that informally link one person to others such as friends or family (O'Donnell, Gilmore, Cummins, \& Carson, 2001). Several studies show that the social networks of family entrepreneurs can play a pivotal role in their firm's internationalisation, especially in the early stages. Social networks can 
facilitate international opportunity recognition by providing information about foreign business opportunities or potential business partners (Ellis, 2011; Johanson \& Vahlne, 2003). Close interaction of family members in a family firm allows them to share important and critical information with each other and enhance the chances of opportunity recognition (Barney, Clark, \& Alvarez, 2003). Although family ties may provide a trusted source of information about new opportunities, they are less likely to produce new and different information (Burt, 1992; Granovetter, 1973; Hayton, et al., 2011). Similarly, Ozgen and Baron (2007) report that social relationships with family members and close friends do not increase entrepreneurs' ability to recognise more opportunities.

Business networks. A business network consists of firm-level relationships linking one firm to other firms (Easton \& $\mathrm{Ha}^{\circ}$ kansson, 1996). Business networks usually consist of competitors, suppliers, customers, distributors, and government bodies (Axelsson \& Johanson, 1992). Ozgen and Baron (2007) find that the number of ties a firm has with mentors and informal industrial networks is positively related to its opportunity recognition. Kontinen and Ojala (2011b) report that family SMEs recognise international opportunities through their business networks rather than their social ties or family ties. It is assumed that managers interact with business networks and hence these networks can provide them with unique information that may not be available through their social ties (Burt, 2004; Granovetter, 1973; Singh, 2000).

\subsection{Prior knowledge}

According to the Austrian school of thought, the identification of opportunities hinges on access to the valuable information to which entrepreneurs are exposed (Shane, 2000). Entrepreneurs' prior knowledge enables them to notice additional information that is related to the information they already have (Shane, 2000). Education, lifestyle, and work experience help people to recognise opportunities (Venkataraman, 1997). Prior knowledge affects the family entrepreneur's ability to understand, extrapolate, interpret, and employ new information in a specific way (Roberts, 1991). Shane (1999) maintains that, because of their prior knowledge, entrepreneurs are able to recognise the value of the new information that they happen to receive, which leads to the recognition of new opportunities. Kontinen and Ojala (2011a) classify prior knowledge in the context of international business into (a) 
industry-specific knowledge, (b) internationalisation knowledge, and (c) market-specific knowledge.

Industry-specific knowledge refers to the knowledge related to technology and the way of doing business in an industry, which enables a firm to recognise new market opportunities in the industry (Park, 2005). Previous experiences and close relationships with specific customers, suppliers, or shareholders can give the entrepreneur specific industry knowledge (Westhead \& Wright, 2001). Westhead and Wright (2001) suggest that those with greater specific knowledge of their industry have a higher propensity to internationalise. Similarly, Cohen and Levinthal (1990) argue that a lack of such knowledge can be a barrier to entering an industry. Internationalisation knowledge can be defined as "the information, beliefs, and skills that organizations can apply to their internationalisation activities" (Fernhaber, McDougall-Covin, \& Shepherd, 2009, p.299). It can be acquired through the media (Johanson \& Vahlne, 1977) and can be transferred from one country to another, allowing firms to engage in similar activities in different countries (Schuster \& Holtbrügge, 2012). Market-specific knowledge, in contrast, refers to knowledge about a specific market's characteristics, structure, business climate, and cultural patterns, as well as the characteristics of the individual customers in that market (Schuster \& Holtbrügge, 2012, p. 818).

In their study of Finnish family SMEs entering the French market, Kontinen and Ojala (2011a) find that prior knowledge does not play a significant role in international opportunity recognition. According to them, despite these firms' strong knowledge of the industry in their own country, they did not have knowledge about the industry in other European countries or what was being offered by their international competitors. Regarding market-specific knowledge, most of the firms had little knowledge of the French market. Even those firms that did have a general understanding of the French culture and language could not use this knowledge for the purpose of international opportunity recognition as it was not directly related to their business. The authors also report that the internationalisation knowledge in the majority of their cases was medium. In contrast to their study, several studies indicate prior international experience to be a positive factor in the recognition of international opportunities (Cavusgil, Knight, \& Riesenberger, 2012; Chandra, et al., 2009; Oviatt \& McDougall, 2005; Weerawardenaa, Sullivan Mortb, Liescha, \& Knight, 2007). 
The current debates about international opportunity identification in the context of family firms can be summarised as in Figure 1 below:

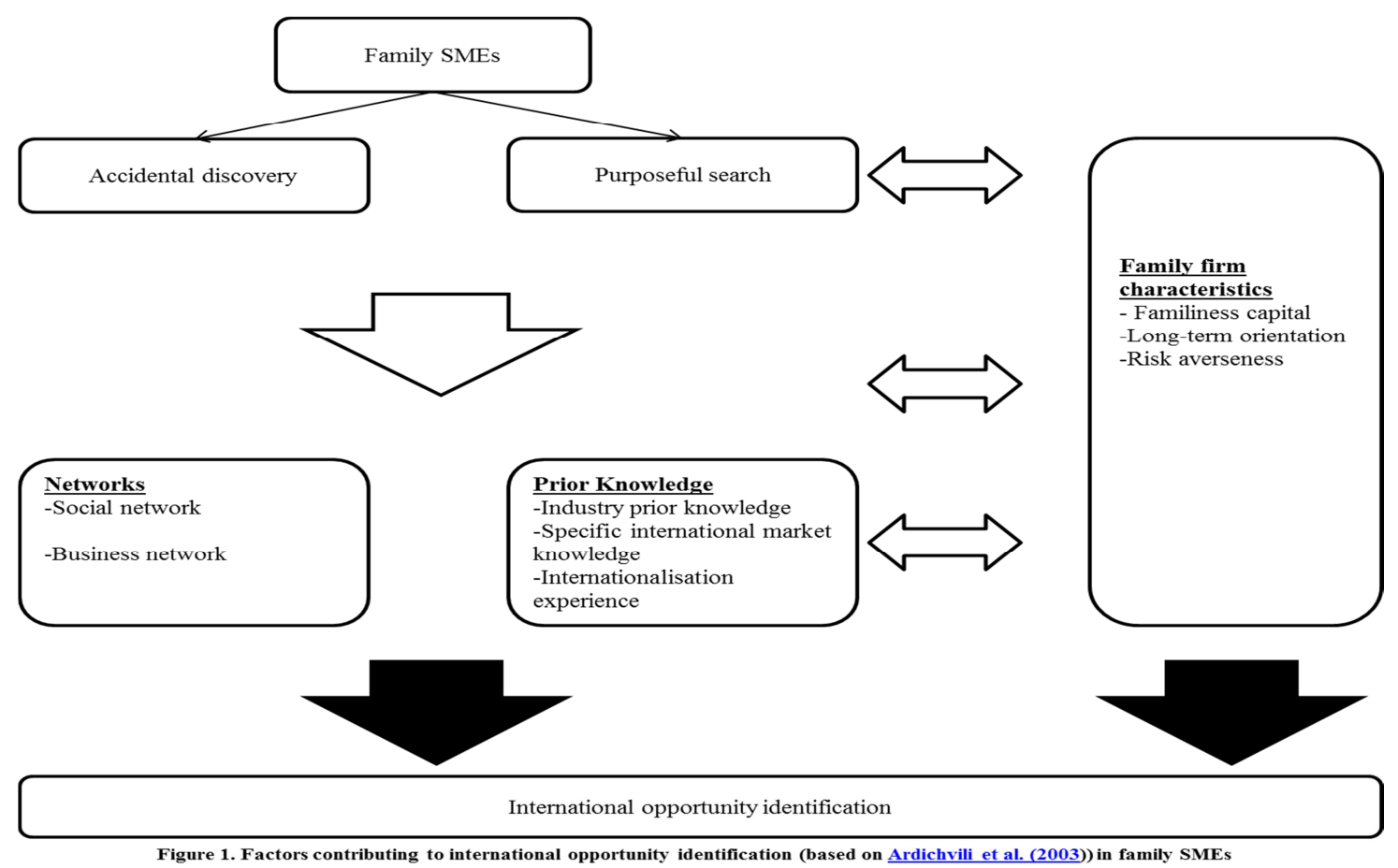

\section{$4 \quad$ Research methodology}

To understand how international opportunities are identified among family firms and how being a family firm can play a role in this process, inductive, exploratory, qualitative case study research has been conducted (Ghauri \& Gronhaug, 2010; Yin, 2009). The qualitative method enables the researcher to understand the context-specific depth of a phenomenon (Bamberger, 2000). The multiple case study approach has been employed as it allows the researcher to study patterns that are common among cases and enables theory building (Eisenhardt \& Graebner, 2007; Stake, 1995).

Family firms from three growing, emerging economies (India, Turkey, and Taiwan) (Eren-Erdogmus, Cobanoglu, Yalcin, \& Ghauri, 2010; Garten, 1997) were selected based on convenience sampling. The selection of different countries provides a high degree of variation in the international opportunity identification behaviour of these firms (Estrin, Meyer, Wright, \& Foliano, 2008). Emerging economies were selected as there is less research investigating international opportunity identification by family SMEs in these countries, and 
further research exploring potential differences between family firms from these and other countries has been suggested (Kontinen \& Ojala, 2010). In addition, family SMEs constitute a considerable proportion of the businesses in these countries (e.g., Bernard, 2013; Calişkan, 2008). For example, statistics illustrate that $90 \%$ of enterprises in Turkey are family firms (Calişkan, 2008). In India, family businesses account for almost two-thirds of India's GDP, and their gross output is around $90 \%$ of India's industrial output (Bernard, 2013). In the context of Taiwan, studies show that the majority of the firms entering international markets are family firms (Hsiang-lan, 2011).

The choice of SMEs (fewer than 250 employees) was made for several reasons. First, the importance of SMEs and the necessity of learning about their behaviour as key entities contributing to national economies have been emphasised in prior studies (OECD, 1997). This research responds to these calls to provide a better understanding of their behaviour in identifying international opportunities (Kontinen \& Ojala, 2010). Second, most researchers to date have focused on the internationalisation of large businesses (Coviello \& Munro, 1997; Graves \& Thomas, 2008) and most of the theories have been designed for and empirically tested on large organisations, which have access to enormous resources for internationalisation. However, research shows that there are differences in the behaviour of large organisations and small firms (Crick \& Spence, 2005; Hulbert, Gilmore, \& Carson, 2013) and that the existing theories may not be readily applicable to SMEs that have limited resources, expertise, and internationalisation experience (He \& Wei, 2011; Hitt, Bierman, Uhlenbruck, \& Shimizu, 2006; Hulbert, et al., 2013).

Consistent with the family firm definition (Abdellatif, et al., 2010) outlined earlier in this article, company cases that met all three criteria were selected. To minimise the effect of industry type on international opportunity identification, company cases were selected only from the manufacturing sector (Graves \& Thomas, 2008; Wincent, Thorgren, \& Anokhin, 2014). See Table 1 for an overview.

\begin{tabular}{|c|c|c|c|c|c|c|c|}
\hline $\begin{array}{l}\text { Name of } \\
\text { company* }\end{array}$ & $\begin{array}{l}\text { Manufacturing } \\
\text { sector }\end{array}$ & $\begin{array}{l}\text { Country of } \\
\text { origin }\end{array}$ & $\begin{array}{l}\text { Year of } \\
\text { establishment }\end{array}$ & $\begin{array}{l}\text { Family } \\
\text { ownership }\end{array}$ & $\begin{array}{l}\text { Generation } \\
\text { with } \\
\text { ownership }\end{array}$ & $\begin{array}{l}\text { Number } \\
\text { of } \\
\text { employees }\end{array}$ & $\begin{array}{l}\text { Percentage } \\
\text { of } \\
\text { international } \\
\text { sales in } \\
2012\end{array}$ \\
\hline
\end{tabular}




\begin{tabular}{|c|c|c|c|c|c|c|c|}
\hline $\begin{array}{l}\text { Book } \\
\text { Publication }\end{array}$ & Publishing & India & 1954 & $100 \%$ & $3^{\text {rd }}$ & 180 & $17 \%$ \\
\hline $\begin{array}{l}\text { Mat } \\
\text { International }\end{array}$ & $\begin{array}{l}\text { Coir } \\
\text { manufacturing }\end{array}$ & India & 2005 & $65 \%$ & $2^{\text {nd }}$ & 78 & $100 \%$ \\
\hline $\begin{array}{l}\text { Leather } \\
\text { Goods }\end{array}$ & $\begin{array}{l}\text { Leather and } \\
\text { leather products }\end{array}$ & India & 1998 & $100 \%$ & $2^{\text {nd }}$ & 10 & $100 \%$ \\
\hline $\begin{array}{l}\text { Packaging } \\
\text { Co. }\end{array}$ & Packaging bags & Turkey & 1987 & $100 \%$ & $3^{\text {rd }}$ & 43 & $75 \%$ \\
\hline $\begin{array}{l}\text { Cookware } \\
\text { Co. }\end{array}$ & Cookware & Turkey & 1980 & $100 \%$ & $2^{\text {nd }}$ & 100 & $82 \%$ \\
\hline $\begin{array}{l}\text { Beverage } \\
\text { Manufacturer }\end{array}$ & $\begin{array}{l}\text { Food } \\
\text { manufacturing }\end{array}$ & Taiwan & 1988 & $100 \%$ & $2^{\text {nd }}$ & 200 & $65 \%$ \\
\hline Bicycle Co. & $\begin{array}{l}\text { Aluminium } \\
\text { bicycle frames }\end{array}$ & Taiwan & 1986 & $100 \%$ & $3^{\text {rd }}$ & 60 & $50 \%$ \\
\hline
\end{tabular}

*: The names of the companies have been changed for confidentiality purposes.

The main method used for collecting primary data was semi-structured interviews. Semi-structured, open-ended interviews allow for the asking of "main" questions, backed up with more detailed questions as necessary (Yin, 2009). An interview guide was developed based on the literature review (see Appendix A). This enhanced the reliability by ensuring that the same information was collected from all cases (Miles \& Huberman, 1994; Yin, 2009). The interviewees were first asked to describe their business in general, and then the internationalisation process used by their firm. Particular attention was given to how international opportunities were recognised as well as the role of family characteristics in this phenomenon. Most of the interviews were conducted in English by one of the authors and two other researchers, one of them from the home country of the case firm and fluent in both the language of that country and English. When necessary, the latter researcher was able to explain questions in a language in which the interviewee was more comfortable. The interviews with case companies from Taiwan were conducted in Taiwanese only as the interviewees were not fluent in English. These interviews were translated into English and verified by another Taiwanese speaker.

Altogether, 16 interviews were conducted, digitally recorded, and transcribed. The interviews lasted between 45 and 90 minutes, and the interviewees included founders, CEOs, and foreign trade managers who had in-depth knowledge about the firms' international 
opportunity identification. The numbers of interviews and positions of the interviewees from each company are outlined in Table 2.

\begin{tabular}{|c|c|c|c|}
\hline Name of company & $\begin{array}{l}\text { Number of } \\
\text { interviews } \\
\text { with an } \\
\text { interviewee }\end{array}$ & Position of the interviewee & $\begin{array}{l}\text { Generation (within } \\
\text { the family) of } \\
\text { interviewee }\end{array}$ \\
\hline Book Publication & 1 & Business Development Manager & $3^{\text {rd }}$ \\
\hline \multirow[t]{2}{*}{ Mat International } & 2 & Director and board member & $2^{\text {nd }}$ \\
\hline & 2 & - Owner & $1^{\mathrm{st}}$ \\
\hline Leather Goods & 3 & - Managing Director & $2^{\text {nd }}$ \\
\hline \multirow[t]{2}{*}{ Packaging Co. } & 3 & Manager of Foreign Trade & $2^{\text {nd }}$ \\
\hline & 1 & - Vice President & $2^{\text {nd }}$ \\
\hline Cookware Co. & 2 & - Marketing Coordinator & $2^{\text {nd }}$ \\
\hline $\begin{array}{l}\text { Beverage } \\
\text { Manufacturer }\end{array}$ & 1 & CEO & $1^{\mathrm{st}}$ \\
\hline Bicycle Co. & 1 & $\begin{array}{l}\text { President's Special Assistant } \\
\text { and salesman }\end{array}$ & $2^{\text {nd }}$ \\
\hline
\end{tabular}

In addition to the primary data, secondary sources such as company websites and reports were employed to facilitate triangulation (Miles \& Huberman, 1994). For the data analysis, the procedure suggested by Ghauri (2004) was followed. A case story, incorporating a chronological order of events, was written for each firm. Then, based on the literature review and research questions, data coding was carried out for each company by two of the researchers independently, and then discussed among them and agreed upon. Separate case 
analyses of each company were developed from the primary and secondary data. Patternmatching logic was used for the analysis of the multiple cases, as suggested by Miles and Huberman (1994).

\section{$5 \quad$ Results}

\subsection{Family firm characteristics}

Familiness capital, long-term orientation and risk averseness characteristics were present in the interviewed family firms. In this section, we explain several examples illustrating these characteristics in different activities of family firms and in the next section highlight how each of these characteristics played a role in international opportunity identification.

Familiness capital was considered a key resource in all family cases. One of the interviewees in Packaging Co., for example, explained:

"Consider two companies, one family firm and one non-family firm. In the family firm, all departments have an owner, have a man and they are from your family and they want to do something good for the company... which company do you think will be more successful? People can work but they are thinking about their salaries... they do not think about the company's benefits. But family members think about their future and company's future.”

It was also very important for the majority of the company cases that top managers of the company were from the family because the family entrepreneur could trust them (e.g., in the case of Cookware Co., Book Publication, Packaging Co., Beverage Manufacturer and Bicycle Co.).

Family firms sometimes combined familiness capital and long-term orientation to achieve their goals. An interviewee in Packaging Co., for example, mentioned that because of the long-term orientation of the firm and the possibility of relying on familiness capital, they decided to invest more in their business and start manufacturing mesh bags instead of only working as a trader of mesh bags, as reflected in the following excerpt: 
"How can I say, based on our family values...my grandfather wants to improve its business all the time. For that reason, he always thinks about new ideas. So, he decided and said that "I should make a new factory for this business and my sons can help me." Then he told my father and my uncles and they accepted and he began his business."

In addition, children of family members are considered as the future leaders of the company and are sent to study courses related to the family firm's needs (e.g., in the case of Book Publication, Mat International, Packaging Co., Beverage Manufacturer and Bicycle Co.).

Interviewed companies were also risk averse. Some of the interviewees highlighted this explicitly. For example, one of the interviewees in Cookware Co. stressed,

“... Compared to nonfamily firms, we are very concerned about the risk; we think it is important to be aware of the risk in our operations."

Low risk taking culture could also be inferred from different activities of interviewed cases. For example, all family firms (except Book Publication) preferred less risky modes of entry like exporting rather than foreign direct investment in all of their international market entries over the years (Claver, Rienda, \& Quer, 2007; Graves \& Thomas, 2008). In the case of Book Publication, the company has entered Singapore through foreign direct investment and its other international market entries are based on exporting. A Beverage Manufacturer interviewee stated,

"We do not want to take huge risk and the best way to avoid uncertainty and risk during internationalisation is exporting."

In addition, internationalisation was pursued gradually and step-by-step, collecting a large amount of information to reduce the risk of failure. It took Book Publication 10 years to successfully start and run its business in Singapore. The family entrepreneur spent four years in Singapore to gather information about the market, industry and running a business before establishing its publication manufacturing there. Another example in this case was related to their financing strategies. One of the interviewees emphasised that in their family firm it had been decided that the strategies of the firm should be developed based only on internal financial resources (firm or family members) and that no loans should be sought. Reluctance 
of family firms to rely on external financial resources because of family firm characteristics has also been highlighted in prior studies (Graves \& Thomas, 2008).

\subsection{Accidental discovery versus purposeful search in family firms}

Being risk averse, none of the family firms in this research intended to internationalise or initiated their first identification of an international opportunity. Instead, they happened to receive some information about an international opportunity and then decided to pursue it. Book Publication, for example, entered the Singapore market only after a friend of the family, who had lived there for a while, suggested they consider that market too. This alerted the company in terms of accidental discovery. Similarly, Cookware Co. entered Germany, Mat International entered China, and Leather Goods entered Italy after friends or family members had suggested that those markets represented good opportunities. In the case of Packaging Co. and Bicycle Co., the companies received unsolicited orders from Germany and the US respectively. The following three excerpts from the interviews refer to these first international opportunities and how they came about through accidental discovery:

"The US was the first foreign customer that approached us directly. They noticed our frame quality when they visited one of the bike assembly companies in Taiwan and got our contact details through the assembly company." (Bicycle Co.)

"It was a close friend of the family who advised the firm to expand into Germany." (Cookware Co.)

“My grandfather's friend, who already had a business there [in Singapore], was into computer components and told him to try to go there and get his computer books published because the market had the highest margins at that time." (Book Publication Co.)

In addition, the majority of the family firms had attempted to reduce their risk by collecting more information about the opportunity that they had recognised through accidental discovery. For example, when Cookware Co. heard about the potential opportunities in Germany, it started attending trade exhibitions in that country to collect more information and search for potential customers there. 
Identification of subsequent international opportunities is impacted by the long-term orientation of the family firms. Considering the necessity of ensuring that the business continues for the next generation, when family firms learn about internationalisation and how to reduce their risk in the international arena and earn a profit there, they pursue a purposeful search strategy to identify more international opportunities.

As part of their purposeful search to identify subsequent international opportunities, the family firms have engaged in various initiatives. All of them have attended trade exhibitions to introduce their products to potential customers in other countries. Book Publication, for example, has identified key trade exhibitions in Pakistan, Bangladesh and Sri Lanka, and attended them in order to identify and sell to potential dealers and distributors there.

In addition to trade shows, some of the family firms have started doing research on different markets. Leather Goods has obtained a lot of valuable information from the Leather Council in India, which provides statistics and information about attractive markets. They have used this source to learn more about the markets in both Italy and Spain. Packaging Co. has conducted international market research and identified countries where companies are buying mesh bags to complement their own products. For example, farmers in Russia own huge onion and potato plantations, and require mesh bags for their packaging. The company has identified key customers in this market and approached them with a view to selling its products to them.

The family firms have also utilised the internet to promote their products in international markets. For example, Beverage Manufacturer and Packaging Co., which have expanded into many other countries, have been very active in advertising their activities on several websites, including www.Alibaba.com. Packaging Co. also has a website in Turkish, English and 50 other languages to enable potential customers to find out about it.

Some of the companies have also prepared brochures explaining their activities and products, which have been distributed in foreign countries by their own governments. Packaging Co. was able to enter the Egyptian market using this strategy:

“The Turkish Government wanted to improve Turkish suppliers' exporting. For this reason, we gave our company's details to the Foreign Trade Undersecretary. 
Egyptian customers asked the Turkish ambassadors about us, and after that they contacted us."

Finally, it should be noted that, in their recognition of subsequent international opportunities, the family SMEs still received unsolicited information about international opportunities. However, they became more proactive and utilised that information as a basis for purposeful searching. For example, after entering the German market, Cookware Co. heard from one of its customers in Turkey about the potential market in Russia. It then set out to learn about the Russian market by hiring a new graduate who was fluent in Turkish and Russian.

\section{$5.3 \quad$ Network ties}

Both social and business networks have proved critical to these family companies' identification of international opportunities (see Table 3). In this section, the analysis commences with social networks before going on to cover business networks. Due to the nature of this study and importance of family network, we present the findings related to social networks in two categories: friends and family members not working for the firm, and family members working for the firm.

\subsubsection{Friends and family members not working for the firm}

\begin{tabular}{|c|c|c|}
\hline Firm & International market entered & International opportunity identification through... \\
\hline \multirow[t]{6}{*}{ Book Publication } & Singapore & $\begin{array}{l}\text { Founders' friend who worked in the same industry in } \\
\text { Singapore }\end{array}$ \\
\hline & Pakistan & \multirow{3}{*}{$\begin{array}{l}\text { Learning about trade exhibitions in the countries through } \\
\text { government websites, and then, after attending trade } \\
\text { exhibitions and with the help of government bodies, } \\
\text { identifying dealers and distributors in each country }\end{array}$} \\
\hline & Bangladesh & \\
\hline & Sri Lanka & \\
\hline & Ghana & $\begin{array}{l}\text { Dealers and distributors in India telling the company about } \\
\text { the potential opportunity, after which the company } \\
\text { initiated a formal search }\end{array}$ \\
\hline & Nigeria & $\begin{array}{l}\text { Dealers and distributors in Ghana selling the products in } \\
\text { Nigeria }\end{array}$ \\
\hline Mat International & China & Friends of the founder in the UAE introducing Chinese \\
\hline
\end{tabular}




\begin{tabular}{|c|c|c|}
\hline & & agents to the company \\
\hline & China & $\begin{array}{l}\text { Later, attending trade exhibitions in China and receiving } \\
\text { more orders from China }\end{array}$ \\
\hline & $\begin{array}{l}\text { Middle East (the UAE, } \\
\text { Syria, Iraq) }\end{array}$ & $\begin{array}{l}\text { Friends of the founder in the UAE introducing him to some } \\
\text { agents that were supplying the Middle East }\end{array}$ \\
\hline & Germany & \multirow{3}{*}{$\begin{array}{l}\text { The provision of trade exhibition information by } \\
\text { government bodies and the attending of trade exhibitions } \\
\text { in Germany; receiving orders from agents supplying } \\
\text { several countries }\end{array}$} \\
\hline & US & \\
\hline & UK & \\
\hline \multirow[t]{3}{*}{ Leather Goods } & Italy & $\begin{array}{l}\text { Other family members involved in exporting who had } \\
\text { already established a network in Italy }\end{array}$ \\
\hline & Spain & $\begin{array}{l}\text { The networks in Italy, as a result of which the opportunity } \\
\text { in Spain was recognised and then a partnership with an } \\
\text { agency in Spain was developed in order to enter the market }\end{array}$ \\
\hline & Kuwait & Attending a trade exhibition \\
\hline \multirow[t]{6}{*}{ Packaging Co. } & Germany & Receiving an order from a customer in Germany \\
\hline & Egypt & $\begin{array}{l}\text { Receiving an order from a customer that had learned about } \\
\text { the firm through a government export promotion document } \\
\text { that was distributed in several countries including Egypt }\end{array}$ \\
\hline & Russia & Formal search \\
\hline & Azerbaijan & $\begin{array}{l}\text { Formal search, identification of customers, selling to one } \\
\text { and then receiving further orders from that customer's } \\
\text { competitors in the same country }\end{array}$ \\
\hline & Yemen & $\begin{array}{l}\text { Formal searching, identifying potential customers through } \\
\text { the internet, seeking more information about them through } \\
\text { government bodies, and contacting them with a view to } \\
\text { selling the products to them }\end{array}$ \\
\hline & $\begin{array}{l}\text { Netherlands, Finland, Latvia, } \\
\text { Norway, Poland, Bulgaria, } \\
\text { Greece, Spain }\end{array}$ & $\begin{array}{l}\text { Promoting the company's products on different websites } \\
\text { and receiving orders from customers }\end{array}$ \\
\hline \multirow[t]{3}{*}{ Cookware Co. } & Germany & $\begin{array}{l}\text { A friend of the CEO who had previously worked for a } \\
\text { competitor in Turkey and then emigrated to Germany; also } \\
\text { through following the suggestions of government bodies to } \\
\text { attend trade exhibitions in Germany }\end{array}$ \\
\hline & Russia & $\begin{array}{l}\text { One of the firm's customers in Turkey who suggested } \\
\text { Russia as a good market, after which the firm employed a } \\
\text { Russian person and began attending trade exhibitions in } \\
\text { Russia }\end{array}$ \\
\hline & Slovenia & Attending trade exhibitions \\
\hline
\end{tabular}




\begin{tabular}{|l|l|l|}
\hline & Czech Republic & Attending trade exhibitions \\
\hline $\begin{array}{l}\text { Beverage } \\
\text { Manufacturer }\end{array}$ & Singapore & $\begin{array}{l}\text { A friend of the CEO in Singapore who wanted to sell } \\
\text { Beverage Manufacturer's products there }\end{array}$ \\
\cline { 2 - 3 } & Hong Kong & Attending trade exhibitions \\
\cline { 2 - 3 } & $\begin{array}{l}\text { Over 50 countries in Europe } \\
\text { and Asia, as well as } \\
\text { Australia and the US }\end{array}$ & Attending trade exhibitions \\
\hline Bicycle Co. & US & $\begin{array}{l}\text { US customers of an assembly firm in Taiwan learning } \\
\text { about Bicycle Co. through that firm }\end{array}$ \\
\cline { 2 - 3 } & Switzerland & $\begin{array}{l}\text { Swiss customers of an assembly firm in Taiwan learning } \\
\text { about Bicycle Co. through that firm }\end{array}$ \\
\cline { 2 - 3 } & Various European countries & Trade exhibitions \\
\hline
\end{tabular}

In the majority of cases (Book Publication, Mat International, Cookware Co. and Beverage Manufacturer) while family firms did not have any intentions of entering international markets, they were encouraged to enter international markets because of the information they happened to receive from friends and family members (who were not working for the firm). For example, the CEO of Beverage Manufacturer had a friend in Singapore who approached the company with the idea of selling its products in that market. Mat International, meanwhile, learned about the Chinese market, and gained access to agents there, as a result of a meeting with some friends in Dubai:

“...My dad had a lot of friends in Dubai, in the Middle East, and we came across agents from China who wanted the raw materials... People from China came to the Middle East and they had a meeting and some of our common friends met each other and talked about the business...."

In one of the companies, family members (not working for the company) facilitated the first instance of international opportunity recognition. Leather Goods found out about the opportunity to sell leather products in Italy from family members who were already active in exporting products and had established networks in Italy. The manager of the firm stated:

"A few of my family members were also in the export business and gave us a lot of help and support to develop and grow our firm." 


\subsubsection{Family members working for the firm}

Family members working for the firms also contributed to international opportunity identification. Familiness capital enabled the firms to identify international opportunities through several strategies. First, strong and highly trusting relationships between the family members working in the companies meant that the majority of the companies preferred to have family members working on the recognition of international opportunities, trusting them to care more about the success of the firm. The founder of Beverage Manufacturer, for example, preferred to have his daughter attend trade exhibitions, believing that, as the success of the family business was important to her, she would be more alert to potential opportunities.

Long-term orientation of company cases also played a role in international opportunity identification. For example, some of the family firms have developed long-term plans for their internationalisation and employed their familiness capital to carry them out. Packaging Co., for example, has identified countries into which it wants to expand in the long-term and sent members of the third generation of the family to study in those countries so as to learn their language and culture and establish networks there. As noted by an interviewee from one of the companies,

"I graduated in International Management from a university in Cyprus. What can I say? We had a plan in our family; my brother and my father and I had a little meeting about our future. And my father said that we needed staff working on foreign trade and an operations manager. For that reason, I chose international management, my brother studied at a university in Lithuania, and my third brother is presently attending a university in China."

Similarly, Book Publication, Mat International, and Beverage Manufacturer have all sent members of the second and/or third generations of their families to study abroad. In the case of Cookware Co., since the members of the third generation are still very young, such a strategy is not yet being pursued (see Table 4). 
Table 4 - Family initiatives for the identification of future international opportunities

\begin{tabular}{|c|c|c|}
\hline Firm & $\begin{array}{l}\text { Family members } \\
\text { working in the } \\
\text { company }\end{array}$ & $\begin{array}{l}\text { Initiatives aimed at the identification of future } \\
\text { international opportunities }\end{array}$ \\
\hline $\begin{array}{l}\text { Book } \\
\text { Publication }\end{array}$ & $\begin{array}{l}\text { Father, five sons, } \\
\text { and grandchildren }\end{array}$ & $\begin{array}{l}\text { Two of the grandchildren have been sent to the UK. } \\
\text { One studied international business and the other is } \\
\text { studying publishing. }\end{array}$ \\
\hline $\begin{array}{l}\text { Mat } \\
\text { International }\end{array}$ & Father and son & Son was sent to the UK to study international business. \\
\hline Leather Goods & Father and son & Not applicable \\
\hline Packaging Co. & $\begin{array}{l}\text { Father, four sons, } \\
\text { and grandchildren }\end{array}$ & $\begin{array}{l}\text { Family members have learned English, German, } \\
\text { Russian, Arabic, and Chinese. } \\
\text { Grandchildren (third generation) have been sent to } \\
\text { China, Russia, the US, and Cyprus for education and to } \\
\text { develop the company's business in those countries. }\end{array}$ \\
\hline Cookware Co. & $\begin{array}{l}\text { Father, two } \\
\text { daughters, and his } \\
\text { wife }\end{array}$ & Not applicable \\
\hline $\begin{array}{l}\text { Beverage } \\
\text { Manufacturer }\end{array}$ & $\begin{array}{l}\text { Father, his wife, his } \\
\text { son, and his } \\
\text { daughter }\end{array}$ & $\begin{array}{l}\text { Second generation (son and daughter) have received an } \\
\text { international education. The son studied international } \\
\text { business in the UK and the daughter, international trade } \\
\text { and marketing. }\end{array}$ \\
\hline Bicycle Co. & $\begin{array}{l}\text { Father, son and his } \\
\text { wife, and a } \\
\text { grandchild }\end{array}$ & Second generation (son) studied in the US \\
\hline
\end{tabular}

\subsubsection{Business network}

The companies' business networks began to play a more pivotal role after the companies had entered their first international market (see Table 3). The companies have 
benefited from several types of business network, including networks of customers, export agencies, distributors, dealers, and government bodies. While some of the family firms have used their existing business networks, others have tried to develop new business networks by attending trade exhibitions. For example, Beverage Manufacturer has attended many such exhibitions and is now successfully exporting to more than 50 countries.

The high quality of the companies' products and their existing satisfied customers have been helpful in making the companies known to other customers. Bicycle Co., for example, was selling its bicycle frames to an assembly firm in Taiwan when, because of the quality of its products, a company in the US and one in Switzerland became interested in it and learned more about it through the assembly firm. In the case of Packaging Co., one customer's referral in Azerbaijan enabled the company to expand its market in that country:

"In Azerbaijan, we have two customers. One is small and the other one is bigger. First of all, we sold our goods to the small one. He was so happy with our products that the larger customer started buying from us. They came to our factory and saw our machines and goods. After that they gave us a huge order." (Packaging Co.)

In the case of Cookware Co., after the company had managed to sell its products to a key customer in Germany, that customer's competitors approached Cookware Co. and asked if it could buy products from it as well.

Export agencies have also facilitated the identification of international opportunities in some of the cases. Mat International, for example, was able to enter the Middle East after one of the founder's friends in the UAE introduced him to some agents who were supplying Middle Eastern countries. Leather Goods gained access to the market in Spain in a similar way.

Book Publication learned about the opportunity in Ghana through its dealers and distributors in India. After entering the Ghanaian market, its dealers there were also able to sell the products in Nigeria. According to one of the managers,

"We export to Africa via Ghana and our dealers there export to Nigeria. Our dealers in India told us that a lot of our competitors were selling books in Ghana and there were no problems with payments from that country. We do not deal directly with Nigeria but our distributors sell our books in Nigeria as well." 
Government bodies, especially those in Turkey and India, have facilitated the process of obtaining international orders by identifying and suggesting potential markets or trade exhibitions for Book Publication, Mat International, and Cookware Co. Additionally, government bodies in Turkey publish lists describing Turkish companies, and distribute them in other countries (e.g., this helped Packaging Co.). They also provide information about customers in foreign markets and verify their legitimacy:

"In Yemen, we found people through the internet. We then asked the Turkish Ambassador about them and obtained very good reports about them. After that, we contacted them." (Packaging Co.)

\subsection{Prior knowledge}

The prior knowledge of the companies is analysed in terms of industry knowledge, internationalisation experience, and knowledge of specific international markets.

\subsubsection{Industry-specific knowledge}

Industry knowledge is categorised into two groups: country-level and international. All of the family firms were found to have good knowledge of their industries in their home countries and to be producing high-quality products. In this research, international industry knowledge is considered to be knowledge about what is going on in one's own industry in another country. The international industry knowledge of the companies had not been particularly extensive before they had grasped their first international opportunities but it had improved thereafter. As mentioned already, all of the companies had recognised their first international opportunities accidentally. It should be noted, however, that family firms were risk averse and did not take the risk of entering an international market without having quite a good amount of knowledge. Although the companies themselves lacked international industry knowledge, network ties with this knowledge had been able to recognise potential opportunities for them. Bicycle Co., for example, received orders from the US and Switzerland when companies there noticed that they were producing frames of a higher quality and at lower prices than were being produced in other countries. Similarly, Packaging Co. did not have very much international industry knowledge when it received its first order from a German company that did have knowledge of the global industry. Similarly, in the 
case of Cookware Co., the company learnt about the market in Germany through a friend who was working in the same industry in Germany, had previously worked for one of the family firm's biggest competitors in Turkey, and thus had quite good knowledge of the industry.

After recognising their first international opportunities, the family firms started attending trade exhibitions to improve their international industry knowledge. There, they could learn about their customers' needs, new technologies, and products. This was pinpointed by interviewees from both Leather Goods and Book Publication:

“Attending trade exhibitions gives us a lot of information, not only about our existing customers and their needs, but also about how to grow our customer base, the changes in demand, and certain other important updates." (Leather Goods)

"We basically take part in book fairs in all these countries and in the process we meet a lot of book dealers, distributors, and publishers, and these guys are a source of information for us...it is vital that my grandfather attends these book fairs...he goes there constantly because it is so vital for us." (Book Publication)

To enhance their international industry knowledge, some of the companies are also building on their familiness capital and their long-term orientation. Book Publication, for example, has sent one of the third-generation members of its family to the UK to study the industry there and eventually bring that knowledge back to the company:

"My brother is studying Publishing at Oxford Brookes and the only motivation behind this is to learn how to improve our books and how to market them in a better way." (Book Publication)

\subsubsection{Internationalisation experience}

The majority of the family firms (with the exception of Mat International) did not have much, if any, internationalisation experience when they recognised their first international opportunities. As discussed before, at this time, the risk-averse family firms were not planning to enter international markets. However, they were able to learn about the 
internationalisation process through their networks of friends, customers, export agencies, and/or government bodies. Their internationalisation knowledge gradually increased after they had entered their first international markets. Packaging Co. and Beverage Manufacturer seem to have been able to utilise this experience most effectively, expanding into many more countries.

In the case of Mat International, the founder had quite a lot of prior internationalisation experience, having been engaged in exporting for many years in another business and sector. In fact, this founder decided to establish Mat International after learning of the potential in international markets.

\subsubsection{Specific market knowledge}

The family firms did not have specific market knowledge before recognising their first international opportunities either. However, once again, members of their networks did have such knowledge. For example, Beverage Manufacturer was able to enter the Singapore market after a friend there identified the opportunity, and Bicycle Co. expanded into the US and Switzerland through companies in those countries that were already familiar with those markets.

After entering their first international markets, the family firms started to engage in purposeful searching and learning about the specific markets they were targeting, so as to reduce their risk. All of the companies attended trade exhibitions to learn about specific markets and the customer needs in those markets. Cookware Co. also recruited a Russian to facilitate the gathering of market knowledge specific to Russia.

Most of the family firms, having noticed the importance of specific market knowledge, are also using their familiness capital to expand their knowledge and increase their chances of recognising further international opportunities in the future. As has already been mentioned, they are sending their children to live and study in target countries. The following example from Packaging Co. illustrates this point:

"My father thinks that China will be very very strong in the future. For that reason, we want to have a person in our company who speaks Chinese. My brother is therefore studying Business Chinese in China.” 


\section{Discussion}

\subsection{Accidental discovery versus purposeful search in family SMEs}

The findings of this research demonstrate that the approach adopted by the family firms for identifying international opportunities was influenced by their family firm characteristics. Being risk-averse (Naldi, et al., 2007), the company cases in this research were not proactive about seeking internationalisation and the identification of international opportunities, but instead took the accidental discovery route. This is consistent with the findings of other scholars, indicating that family firms engage in strategies with lower risk (Lumpkin, et al., 2010; Naldi, et al., 2007; Schulze, et al., 2002).

In contrast to the identification of the first international opportunity, the majority of the subsequent international opportunities were sought deliberately. As the family firms learned about internationalisation and international opportunity identification, they were able to reduce the risk of internationalisation (George, Wiklund, \& Zahra, 2005; Hayton, et al., 2011). Hayton, et al. (2011) pinpoint that family SMEs recognise opportunities as a result of accumulating information. Moreover, after learning how to do business internationally, and considering the necessity of keeping their business going for future generations (Zellweger, 2007), the family firms started to embrace internationalisation in their long-term agendas and to search more systematically for opportunities. This is consistent with the proposition of Zellweger (2007) that the importance of long-term survival can guide the strategies that family firms pursue.

The findings of our research contradict the suggestion of Kontinen and Ojala (2011a) that family firms are not active even in searching for subsequent opportunities. In fact, in line with Graves and Thomas (2008), we highlight that family firms are not proactive in identifying their first opportunity but will engage more proactively in a systematic search for subsequent opportunities.

In accordance with the argument of Murphy and Coombes (2009) and in contrast to studies that consider the identification of opportunities to be achieved either through accidental discovery (Ardichvili, et al., 2003; Koller, 1988; Teach \& Schwartz, 1989) or through purposeful search (Fiet, et al., 2005), the findings of this research highlight that there is not a dichotomy. Instead, family firms combine accidental discovery with purposeful 
search. Systematic search reduces environmental uncertainty which better suits the riskaverse nature of family firms (Patel \& Fiet, 2009). On the basis of the findings of this research, we posit the following:

Proposition 1a: Because of their nature (being risk averse and long-term oriented), family firms are more likely to identify their first international opportunity through accidental discovery and subsequent international opportunities through purposeful search.

Proposition 1b: Family SMEs complement accidental discovery with purposeful search to reduce their risk.

\subsection{Network ties}

The majority of the family firms studied in this research (five out of seven) found their first international opportunity through a social network, namely through a friend or a family member who was not working for the company. This is consistent with prior studies confirming the role of social networks in the identification of international opportunities (Ellis, 2011; Komulainen, Mainela, \& Tahtinen, 2006; Zain \& Ng, 2006). However, our findings contradict those studies that suggest that social ties do not play a role in international opportunity identification (Kontinen \& Ojala, 2011a, 2011b; Ozgen \& Baron, 2007). In fact, the findings of this research shed light on the apparently contradictory results of prior studies. We reveal that social ties can facilitate the process of opportunity identification when the social contacts have related knowledge (e.g. in the case of Leather Goods and Book Publication).

This research also highlights the role of family members working in family firms who shape the firms' characteristics. For example, we show that the case companies build on their familiness capital by employing family members in the task of international opportunity identification. They prefer to use family members for this role as they know they can trust them. This is consistent with the prior studies suggesting that the interaction between family members fosters trust among them (Bubolz, 2001) and arguing that family firms can use the social interactions among family members to create value (Salvato \& Melin, 2008).

In line with prior studies in the field of international business (Coviello \& Munro, 1997; Loane \& Bell, 2006; Vasilchenko \& Morrish, 2011) and regarding family firms 
(Kontinen \& Ojala, 2011a), our findings indicate that family firms also use their business networks to identify international opportunities. The business networks were found to play a more prominent role in the identification of subsequent international opportunities. Supporting the findings of Gençtürk and Kotabe (2001) and Shamsuddoha, Ali, and Oly (2009), our research illustrates that government assistance, in terms of the conducting of market reviews and the provision of foreign market information, facilitated the identification of international opportunities for these case firms. This research also endorses prior studies that refer to international trade exhibitions as good opportunities for companies to establish and expand their business networks in international markets (Ellis, 2011; Gopalakrishna, Lilien, Williams, \& Sequeira, 1995; Kontinen \& Ojala, 2011a). Based on our findings, it can thus be proposed that:

Proposition 2a: Family SMEs are more likely to recognise their first international opportunity through social networks and subsequent international opportunities through business networks.

Proposition 2b: The positive relationship between social networks and international opportunity identification will be more positive for social networks that encompass greater knowledge (international industry knowledge, market-specific knowledge, internationalisation knowledge) than for social networks with less knowledge.

\subsection{Prior knowledge}

Studies suggest that prior knowledge is crucial for the recognition of opportunities in domestic markets (Baron, 2006; Shane, 2000) as well as international markets (Oviatt \& McDougall, 2005; Reuber \& Fischer, 1997). The companies interviewed in this research all have a high level of knowledge about the industries in which they are operating in their home countries. This has helped them to produce high-quality products that can be sold in international markets. However, they did not know much about their industries in other countries when they recognised their first international opportunities.

The findings of this research regarding the role of prior knowledge in international opportunity recognition corroborate the proposition of Ardichvili, et al. (2003) but contradict 
the findings of Kontinen and Ojala (2011a) who argue that prior knowledge has no impact on international opportunity identification.

While the findings of this research confirm that international industry knowledge is critical in the recognition of overseas opportunities, family firms do not have to own this knowledge themselves. Instead, they can bridge this knowledge gap through their networks if they contain this knowledge. According to our findings, if family entrepreneurs have a high level of prior knowledge, they will be in a good position to recognise international opportunities. However, even when they do not have the required knowledge, if their networks do contain it then they will still be able to identify international opportunities. Obviously, if both the family entrepreneur and their network have related knowledge, the chances of identifying international opportunities will be even higher.

Based on the findings of this research, it can be proposed that:

Proposition 3a: In the context of family SMEs, there is a positive relationship between an entrepreneur's prior knowledge (international industry knowledge, market-specific knowledge, internationalisation knowledge) and international opportunity identification, and that relationship is moderated by the prior knowledge in their network (social or business).

Family firms are characterised as being long-term oriented. This long-term orientation may impact the strategies used to gain knowledge, and consequently their quest to identify international opportunities. This is corroborated by previous studies suggesting that the longevity of family firms is important to them and that they design their strategies taking this into account (Poza, 2007; Ward, 2004). In most of the cases in this study, the families have employed their familiness capital in sending their children abroad to study in countries that are target markets for the future, so as to gain industry and/or market-specific knowledge. This verifies what other scholars have reported, namely that family firms can benefit from being long-term oriented, developing their own knowledge structures to aid the recognition of international opportunities (Carney, 2005; Patel \& Fiet, 2011).

Proposition 3b: By enhancing the knowledge of the family firm, familiness capital can contribute to long-term international opportunity identification. 


\section{Conclusion}

The aim of this research was to find out how family firms identify international opportunities and how family firm characteristics (familiness capital, long-term orientation, and risk averseness) might play a role in international opportunity identification. Prior studies report mixed findings in relation to the pursuit of accidental discovery versus purposeful search (Fiet, 2007; Graves \& Thomas, 2008; Hayton, et al., 2011), the use of social networks versus business networks (Burt, 1992; Granovetter, 1973; Hayton, et al., 2011; Ozgen \& Baron, 2007), and the use of different types of prior knowledge (Cavusgil, et al., 2012; Chandra, et al., 2009; Kontinen \& Ojala, 2011a; Oviatt \& McDougall, 2005; Weerawardenaa, et al., 2007) in the identification of first or subsequent international opportunities by family firms.

Building upon Ardichvili, et al. (2003) theory of opportunity identification, our findings demonstrate that, family firms are risk averse and are not proactive in entering international markets. However, when they happen to learn about opportunities, they act quickly and pursue them. In this process, they engage in a systematic search for more information in order to reduce their risk. After entering their first international market and gaining experience, they pursue international opportunities more purposefully to create chances for growth and the longevity of the business for subsequent generations. The findings of this research also illustrate that the discovery approach and purposeful search do not represent a dichotomy (Murphy \& Coombes, 2009); instead, family firms engage in both strategies to reduce their risk.

Prior studies regarding the roles of social and business networks are conflicting, some arguing that social networks do not play a role in the context of family firms (e.g., Kontinen \& Ojala, 2011a). We show that family firms can benefit from both social networks and business networks in the identification of international opportunities. While the majority of initial international opportunities are identified through social networks, subsequent opportunities tend to be recognised through business networks. The findings of this research add to the prior understanding by implying that social networks with related knowledge (industry, market, internationalisation experience) can play a role in the identification of opportunities. 
Family members working in these firms can also contribute to international opportunity identification. First, family firms can employ their familiness capital for this purpose, assigning the task to trusted family members. Family firms can also benefit from their long-term orientation, developing an international opportunity identification plan and employing their familiness capital to achieve it.

Regarding prior knowledge, while the findings of this research reveal that having such knowledge is important, we highlight that it is not necessary for the family entrepreneur to possess this knowledge himself/herself. Family firms can still identify international opportunities without prior knowledge, provided that their networks contain this knowledge. Thus, we shed light on the surprising conclusion of Kontinen and Ojala (2011a) that family firms can recognise international opportunities without prior knowledge.

The findings of this research also demonstrate that family firm characteristics such as long-term orientation and familiness capital can contribute towards enhancing the knowledge of family firms in terms of international industry and market knowledge (e.g. by sending their children to study in a country that they are going to enter in future).

This study makes several contributions. First, it offers a new understanding of the opportunity identification theory in the field of international business and highlights the initiation point of internationalisation theories (Styles \& Gray, 2006). Second, it responds to the call for further research on international opportunity identification (Dimitratos \& Jones, 2005; Ellis, 2011) in the context of family firms (Aldrich \& Cliff, 2003; Chrisman, et al., 2005; Kontinen \& Ojala, 2010). Third, although there are a few studies focusing on international opportunity identification by family firms in the US or European countries (e.g., Chandra, et al., 2009; Kontinen \& Ojala, 2011a), this research sheds light on the phenomenon in the context of emerging economies. Fourth, in previous research, opportunity identification has mainly been studied from the perspectives of accidental discovery and purposeful search (Kirzner, 1979; Shane, 2000), network ties (Ellis, 2011; Ozgen \& Baron, 2007), or prior knowledge (Kirzner, 1979; Shane, 2000). However, this paper combines these three aspects to offer a more comprehensive picture in the context of family firms. It also reveals how family firms can build on their family-related advantages to identify international opportunities. Fifth, this research contributes to the prior understanding that had only focused on the identification of "one" international opportunity (Chandra, et al., 2009; Evers \& 
O'Gorman, 2011; Kontinen \& Ojala, 2011a), and offers a more comprehensive view by investigating several international opportunities identified by each case company.

This research has several implications for family firms' managers as well. First, family firms should be alert to the information they may happen to receive about international opportunities. After identifying their first international opportunity, they can employ a more purposeful search strategy to learn about further potential opportunities and reduce their risk. In addition to their social networks, and especially those social contacts with relevant knowledge, they can learn about opportunities by establishing relationships with business networks, made up of entities such as government bodies, export agencies, dealers, etc. Family entrepreneurs can utilise their prior knowledge to identify international opportunities. However, when they lack the required knowledge, they should find networks that do have it and can help them with this process. The managers of family firms can also build on their long-term orientation and utilise their familiness capital to aid their endeavours to identify international opportunities.

This research is not without limitations. First of all, only a limited number of family firms were selected from a small number of emerging economies which constrains the generalisation of the findings of this research. In addition, only manufacturing family firms were interviewed in this research and as a result, the findings of this research may not be applicable to service sector family firms. 


\section{Appendix A - Indicative interview questions}

1. Please introduce yourself and your company.

2. In which industry does your company operate?

3. What do you produce (product/service)?

4. What is your position in the company?

5. What is your position in the family?

6. Please explain the internationalisation process of your firm.

7. How did it start?

8. Which country did you enter first?

9. Why did you select that country as the first point of entry?

10. What was the next country that you entered? (if applicable)

11. How did you recognise a potential opportunity in the foreign market?

12. Through family, friends? (please explain and give examples)

13. Through business networks? (business networks refers to the relationships a firm has with its customers, distributors, suppliers, competitors, government bodies, and other actors) (please explain and give examples)

14. Please explain the role of prior knowledge in international opportunity identification (industry knowledge/international industry knowledge, internationalisation experience, market-specific knowledge)

15. How do you think that being a family business has impacted on your firm's recognition of international opportunities? 


\section{References:}

Abdellatif, M., Amann, B., \& Jaussaud, J. (2010). Family versus nonfamily business: A comparison of international strategies. Journal of Family Business Strategy, 1, 108116.

Aldrich, H. E., \& Cliff, J. E. (2003). The pervasive effects of family on entrepreneurship: toward a family embeddedness perspective. Journal of Business Venturing, 18, 573596.

Ardichvili, A., Cardozo, R., \& Ray, S. (2003). A theory of entrepreneurial opportunity identification and development. Journal of Business Venturing, 18, 105-123.

Axelsson, B., \& Johanson, J. (1992). Foreign market entry: the textbook vs. the network view. In B. Axellson \& G. Easton (Eds.), Industrial Networks: A New View of Reality (pp. 219-234). London: Routledge.

Bamberger, M. (2000). Integrating Quantitative and Qualitative Research in Development Projects. In. Washington, DC: World Bank.

Barney, J. B., Clark, D. N., \& Alvarez, S. (2003). When do family ties matter? Entrepreneurial market opportunity recognition and resource acquisition in family firms. In Babson-Kaufman Entrepreneurship Research Conference.

Baron, R. A. (2006). Opportunity Recognition as Pattern Recognition: How Entrepreneurs "Connect the Dots" to Identify New Business Opportunities. Academy of Management Perspectives, 20, 104-119.

Bernard, C. (2013). Family-owned businesses - the backbone of India's economy. Retreived Access Date|, Access Year|, from URL|.

Bhave, M. P. (1994). A Process Model of Entrepreneurial Venture Creation. Journal of Business Venturing, 9, 223- 242.

Bourdieu, P. (1994). Raisons pratiques. Paris: Essais.

Bubolz, M. M. (2001). Family as source, user, and builder of social capital. Journal of SocioEconomics, 30, 129.

Burt, R. S. (1992). Structural Holes: The Social Structure of Competition. Cambridge, MA: Harvard University Press.

Burt, R. S. (2004). Structural Holes and Good Ideas. American journal of sociology, 110, 349-399.

Calişkan, S. Ş. (2008). Overview of family business relevant issues. In: European Commission.

Carney, M. (2005). Corporate Governance and Competitive Advantage in Family-Controlled Firms. Entrepreneurship: Theory \& Practice, 29, 249-265.

Cavusgil, S. T., Knight, G., \& Riesenberger, J. (2012). International Business: The New Realities (2nd ed.). Upper Saddle River, New Jersey: Pearson.

Chandra, Y., Styles, C., \& Wilkinson, I. (2009). The recognition of first time international entrepreneurial opportunities: Evidence from firms in knowledge-based industries. International Marketing Review, 26, 30-61.

Chrisman, J. J., Chua, J. H., \& Litz, R. (2003). A unified systems perspective of family firm performance: an extension and integration. Journal of Business Venturing, 18, 467472.

Chrisman, J. J., Chua, J. H., \& Steier, L. (2005). Sources and Consequences of Distinctive Familiness: An Introduction. Entrepreneurship: Theory \& Practice, 29, 237-247. 
Claver, E., Rienda, L., \& Quer, D. (2007). The internationalisation process in family firms: choice of market entry strategies. Journal of general management, 33, 1-14.

Cohen, W. M., \& Levinthal, D. A. (1990). Absorptive Capacity: A New Perspective on Learning and Innovation. Administrative Science Quarterly, 35, 128-152.

Coviello, N., \& Munro, H. (1997). Network Relationships and the Internationalisation Process of Small Software Firms. International Business Review, 6, 361-386.

Covin, J. G., \& Slevin, D. P. (1991). A conceptual model of entrepreneurship as firm behaviour. Entrepreneurship: Theory \& Practice, 16, 7-25.

Crick, D., \& Spence, M. (2005). The internationalisation of 'high performing' UK high-tech SMEs: a study of planned and unplanned strategies. International Business Review, $14,167-185$.

Dimitratos, P., \& Jones, M. V. (2005). Future directions for international entrepreneurship research. International Business Review, 14, 119-128.

Easton, G., \& $\mathrm{Ha}^{\circ}$ kansson, H. (1996). Markets as networks: Editorial introduction. International Journal of Research in Marketing, 13, 407-413.

Eckhardt, J. T., \& Shane, S. A. (2003). Opportunities and Entrepreneurship. Journal of management, 29, 333-349.

Eisenhardt, K. M., \& Graebner, M. E. (2007). Theory buidling from cases: Opportunities and challenges. Academy of Management Journal, 50, 25-32.

Ellis, P. D. (2011). Social ties and international entrepreneurship: Opportunities and constraints affecting firm internationalization. Journal of International Business Studies, 42, 99-127.

Eren-Erdogmus, I., Cobanoglu, E., Yalcin, M., \& Ghauri, P. N. (2010). Internationalization of emerging market firms: the case of Turkish retailers. International Marketing Review, 27, 316-337.

Estrin, S., Meyer, K. E., Wright, M., \& Foliano, F. (2008). Export propensity and intensity of subsidiaries in emerging economies. International Business Review, 17, 574-586.

Evers, N., \& O'Gorman, C. (2011). Improvised Internationalization in New Ventures: The Role of Prior Knowledge and Networks. Entrepreneurship and Regional Development, 23, 549-574.

Fernhaber, S. A., McDougall-Covin, P. P., \& Shepherd, D. A. (2009). International entrepreneurship: leveraging internal and external knowledge sources. Strategic Entrepreneurship Journal, 3, 297-320.

Fiet, J. O. (2007). A Prescriptive Analysis of Search and Discovery. Journal of Management Studies, 44, 592-611.

Fiet, J. O., Piskounov, A., \& Patel, P. (2005). Still Searching (Systematically) for Entrepreneurial Discoveries. Small Business Economics, 25, 489-504.

Gaglio, C. M., \& Katz, J. A. (2001). The psychological basis of opportunity identification: entrepreneurial alertness. Small Business Economics, 16, 95-112.

Garten, J. E. (1997). The Big Ten: The Big Emerging Markets and How They will Change Our Lives. New York, NY: Basic Books.

Gençtürk, E. F., \& Kotabe, M. (2001). The Effect of Export Assistance Program Usage on Export Performance: A Contingency Explanation. Journal of International Marketing, 9, 51-72.

George, G., Wiklund, J., \& Zahra, S. A. (2005). Ownership and the Internationalization of Small Firms. Journal of management, 31, 210-233.

Ghauri, P. N. (2004). Designing and conducting case studies in international business research. In R. Marschan-Piekkari \& C. Welch (Eds.), Handbook of qualitative 
research methods for international business (pp. 107-124). Cheltenham, UK: Edward Elgar.

Ghauri, P. N., \& Gronhaug, K. (2010). Research methods in business studies: A practical guide (4th ed.). Harlow: England: Financial Times/ Prentice Hall.

Gopalakrishna, S., Lilien, G. L., Williams, J. D., \& Sequeira, I. K. (1995). Do trade shows pay off? Journal of Marketing, 59, 75-83.

Granovetter, M. (1973). The strength of weak ties. Am. J. Sociol., 78, 1360-1380.

Graves, C., \& Thomas, J. (2008). Determinants of the Internationalization Pathways of Family Firms: An Examination of Family Influence. Family Business Review, 21, 151-167.

Hayton, J., Chandler, G. N., \& DeTienne, D. R. (2011). Entrepreneurial opportunity identification and new firm development processes: a comparison of family and nonfamily new ventures. International Journal of Entrepreneurship \& Innovation Management, 13, 12-31.

He, X., \& Wei, Y. (2011). Linking market orientation to international market selection and international performance. International Business Review, 20, 535-546.

Hitt, M. A., Bierman, L., Uhlenbruck, K., \& Shimizu, K. (2006). The importance of resources in the internationalization of professional service firms: The good, the bad, and the ugly. Academy of Management Journal, 49, 1137-1157.

Hsiang-lan, C. (2011). Internationalization in Taiwanese family firms. Global Journal of Business Research (GJBR), 5, 15-23.

Hulbert, B., Gilmore, A., \& Carson, D. (2013). Sources of opportunities used by growth minded owner managers of small and medium sized enterprises. International Business Review, 22, 293-303.

Johanson, J., \& Vahlne, J.-E. (1977). The internationalization process of the firm: A model of knowledge development and increasing foreign market commitments. Journal of International Business Studies, 8, 23-32.

Johanson, J., \& Vahlne, J.-E. (2003). Business Relationship Learning and Commitment in the Internationalization Process. Journal of International Entrepreneurship, 1, 83-101.

Kirzner, I. M. (1979). Perception, Opportunity and Profit. Chicago, IL: University of Chicago Press.

Kirzner, I. M. (1997). Entrepreneurial Discovery and the Competitive Market Process: An Austrian Approach. Journal of Economic Literature, 35, 60-85.

Koller, R. H. (1988). On the source of entrepreneurial ideas. Frontiers of Entrepreneurship Research. Wellesley, MA: Babson College.

Komulainen, H., Mainela, T., \& Tahtinen, J. (2006). Social networks in the initiation of a high-tech firm's internationalisation. International Journal of Entrepreneurship \& Innovation Management, 6, 526-541.

Kontinen, T., \& Ojala, A. (2010). The internationalization of family businesses: A review of extant research. Journal of Family Business Strategy, 1, 97-107.

Kontinen, T., \& Ojala, A. (2011a). International Opportunity Recognition among Small and Medium-Sized Family Firms. Journal of Small Business Management, 49, 490-514.

Kontinen, T., \& Ojala, A. (2011b). Network ties in the international opportunity recognition of family SMEs. International Business Review, 20, 440-453.

Lee, J.-H., \& Venkataraman, S. (2006). Aspirations, market offerings, and the pursuit of entrepreneurial opportunities. Journal of Business Venturing, 21, 107-123. 
Loane, S., \& Bell, J. (2006). Rapid internationalisation among entrepreneurial firms in Australia, Canada, Ireland and New Zealand. International Marketing Review, 23, 467-485.

Lumpkin, G. T., Brigham, K. H., \& Moss, T. W. (2010). Long-term orientation: Implications for the entrepreneurial orientation and performance of family businesses. Entrepreneurship \& Regional Development, 22, 241-264.

Miles, M. B., \& Huberman, A. M. (1994). An expanded source book qualitative data analysis (2nd ed.). Thousand Oaks: Sage Publications.

Murphy, P., \& Coombes, S. (2009). A Model of Social Entrepreneurial Discovery. Journal of business ethics, 87, 325-336.

Naldi, L., Nordqvist, M., Sjöberg, K., \& Wiklund, J. (2007). Entrepreneurial Orientation, Risk Taking, and Performance in Family Firms. Family Business Review, 20, 33-47.

O'Donnell, A., Gilmore, A., Cummins, D., \& Carson, D. (2001). The network construct in entrepreneurship research: a review and critique. Management Decision, 39, 749-760.

OECD. (1997). Globalisation \& SMEs. In (Vol. 2). Paris: Organization for Economic Cooperation and Development.

Oviatt, B. M., \& McDougall, P. P. (2005). Defining International Entrepreneurship and Modeling the Speed of Internationalization. Entrepreneurship Theory and Practice, 29, 537-553.

Ozgen, E., \& Baron, R. A. (2007). Social sources of information in opportunity recognition: Effects of mentors, industry networks, and professional forums. Journal of Business Venturing, 22, 174-192.

Park, J. S. (2005). Opportunity recognition and product innovation in entrepreneurial hi-tech start-ups: a new perspective and supporting case study. Technovation, 25, 739-752.

Patel, P. C., \& Fiet, J. O. (2009). Systematic Search and Its Relationship to Firm Founding. Entrepreneurship: Theory \& Practice, 33, 501-526.

Patel, P. C., \& Fiet, J. O. (2011). Knowledge Combination and the Potential Advantages of Family Firms in Searching for Opportunities. Entrepreneurship: Theory \& Practice, $35,1179-1197$.

Poza, E. J. (2007). Family business. Mason, OH: Thomson South-Western.

Reuber, A. A. R., \& Fischer, E. E. (1997). The Influence of the Management Team's International Experience on the Internationalization Behaviors of SMES. Journal of International Business Studies, 28, 807-825.

Roberts, E. (1991). Entrepreneurs in High Technology: Lessons from MIT and Beyond. New York: Oxford University Press.

Salvato, C., \& Melin, L. (2008). Creating Value Across Generations in Family-Controlled Businesses: The Role of Family Social Capital. Family Business Review, 21, 259-276.

Sardeshmukh, S. R., \& Corbett, A. C. (2011). The Duality of Internal and External Development of Successors: Opportunity Recognition in Family Firms. Family Business Review, 24, 111-125.

Schulze, W. S., Lubatkin, M. H., \& Dino, R. N. (2002). Altruism, Agency, and the Competitiveness of Family Firms. Managerial \& Decision Economics, 23, 247-259.

Schuster, T., \& Holtbrügge, D. (2012). Market entry of multinational companies in markets at the bottom of the pyramid: A learning perspective. International Business Review, 21, 817-830.

Shamsuddoha, A. K., Ali, M. Y., \& Oly, N. (2009). A conceptualisation of direct and indirect impact of export promotion programs on export performance of smes and entrepreneurial ventures. International Journal of Entrepreneurship, 13, 87-106. 
Shane, S. (1999). Prior knowledge and the discovery of entrepreneurial opportunities. Organizational Science, 11, 448-446.

Shane, S. (2000). Prior knowledge and the discovery of entrepreneurial opportunities. Organization Science, 11, 448-469.

Shane, S., \& Venkataraman, S. (2000). The promise of entrepreneurship as a field of research. Academy of Management Review, 25, 217-226.

Singh, R. P. (2000). Entrepreneurial opportunity recognition through social networks. New York: Garland Publishing Inc. Taylor and Francis Group.

Stake, R. E. (1995). The art of case study research. Thousand Oaks, CA: Sage Publications.

Styles, C., \& Gray, S. (2006). Guest editorial: new perspectives on international entrepreneurship. International Marketing Review, 23, 461-466.

Tang, J., \& Khan, S. A. (2007). Dynamic interactions between alertness and systematic search A yin and yang perspective on opportunity recognition and innovation. The International Journal of Entrepreneurship and Innovation, 8, 175-187.

Teach, R. D., \& Schwartz, R. G. (1989). The recognition and exploitation of opportunity in the software industry: a study of surviving firms. In R. H. Brockhaus, W. C. Churchill, J. Katz, B. A. Kirchhoff, K. H. Vesper \& W. Wetzel (Eds.), Frontiers of Entrepreneurship Research (pp. 383-397).

Vasilchenko, E., \& Morrish, S. (2011). The Role of Entrepreneurial Networks in the Exploration and Exploitation of Internationalization Opportunities by Information and Communication Technology Firms. Journal of International Marketing, 19, 88-105.

Venkataraman, S. (1997). The distinctive domain of entrepreneurship research. In J. A. Katz $\&$ R. H. Brockhaus (Eds.), Advances in entrepreneurship, firm emergence and growth (Vol. 3, pp. 119-138). Greenwich, CT: JAI Press.

Walsh, J. P., \& Seward, J. K. (1990). On the Efficiency of Internal and External Corporate Control Mechanisms. Academy of Management Review, 15, 421-458.

Ward, J. L. (2004). Perpetuating the family business. Marietta, GA: Family Enterprise Publishers.

Weerawardenaa, J., Sullivan Mortb, G., Liescha, P. W., \& Knight, G. A. (2007). Conceptualizing accelerated internationalization in the born global firm: A dynamic capabilities perspective Journal of World Business, 42, 294-306.

Westhead, P., \& Wright, M. (2001). The internationalization of new and small firms: A resource-based view. Journal of Business Venturing, 16, 333.

Wincent, J., Thorgren, S., \& Anokhin, S. (2014). Entrepreneurial orientation and network board diversity in network organizations. Journal of Business Venturing, 29, 327-344.

Yin, R. K. (2009). Case study research: Design and methods (4th ed. Vol. 5). Thousand Oaks: California: Sage Publications.

Zahra, S. A., Korri, J. S., \& JiFeng, Y. (2005). Cognition and international entrepreneurship: implications for research on international opportunity recognition and exploitation. International Business Review, 14, 129-146.

Zain, M., \& Ng, S. I. (2006). The impacts of network relationships on SMEs' internationalization process. Thunderbird International Business Review, 48, 183-205.

Zellweger, T. (2007). Time Horizon, Costs of Equity Capital, and Generic Investment Strategies of Firms. Family Business Review, 20, 1-15. 